\title{
The effect of music therapy on the level of anxiety in the patients undergoing coronary angiography
}

\author{
Meltem Vizeli Doğan ${ }^{1}$, Leman Şenturan ${ }^{2 *}$ \\ ${ }^{1}$ Gulhane Medical Military Academy, Istanbul, Turkey \\ ${ }^{2}$ Halic University School of Health Sciences, Istanbu, Turkey \\ Email: ${ }^{\text {lemansenturan@ } @ \text { halic.edu.tr }}$
}

Received 4 May 2012; revised 31 May 2012; accepted 9 June 2012

\begin{abstract}
The sedative effects of music on healthy and sick individuals are known for centuries. Nowadays, nursing has used the efficacy of music therapy in interventions. The aim of the study was to determine the effect of music, which the patients undergoing a coronary angiography for the first time listened to during the intraoperative period, on the level of anxiety in the patients. The study was conducted experimentally as a pretest/posttest control group design. Data collection form; state-trait anxiety inventory, CDs and CD player were used. Inventories were applied to the patients before the process. The study group (100 patients) listened to music throughout the intervention, whilst the control group (100 patients) listened to no music. At the end of the process, all patients were given the same state anxiety inventory once more. The data was assessed by number, percentage, mean distribution with the paired t-test and $t$ test. It was found that the difference between the mean state anxiety scores obtained before and during the coronary angiography were significantly higher in the study group $(4.04 \pm 1.15)$ than the control group $(2.01 \pm 0.10)(p=0.000)$. It was concluded that the music listened to during the coronary angiography process had an impact on the intraoperative anxiety levels of the patients.
\end{abstract}

Keywords: Music Therapy; Anxiety; Coronary Angiography; Nursing

\section{INTRODUCTION}

The coronary angiography is an invasive and routine procedure in cardiology and makes the individual experience anxiety as all simple or critical invasive procedures [1]. The primary factors for increasing the patient's anxiety are hospitalization, and/or being in the hospital

"Corresponding author. and waiting for a procedure/intervention to be performed $[2,3]$. The meaning of the procedure to the patient, the types of questions they have regarding the procedure, and the degree of clarity they have on what the procedure means to them, and potentially unanswered questions are other factors that also contribute to patient anxiety $[3,4]$.

Healthcare professionals need to identify patient's anxiety and decide what can be done to relieve it [5]. Nurses can use both social and formal non-therapeutic methods to deal with a patient's anxiety in collaboration with other members of the profession. It is well acknowledged how important non-therapeutic nursing approaches are in relieving the patient's anxiety and fear, particularly in the preoperative period.

Music therapy is used for treating, rehabilitation and preventive purposes in alternative therapies called cognitive treatments with their confirmed effects on the modifiability of psychological status [6-9]. It is a therapeutic modality which is performed in a regular program applying physiological and psychological effects of musical sounds and melodies to various psychological disorders [10]. It is a non-invasive relaxation technique in nursing practices, besides it is accepted as an aesthetic therapeutic approach that allows the patients to contribute to their care in accordance with their own ideas $[3,11]$. Professional scientific branches, e.g. physiology, physics, neurology, communications, psychology, all highlight the fact that music is as efficacious as anesthesia and a symbolic tool to relieve anxiety, fear and pain [7,11-13]. Clinical studies with an understanding of active musictherapy are performed in modern medicine for the purpose of treatment principally in cardiology and oncology, and for autism, geriatrics, immunology, neurology, depression, anxiety, etc [7].

In Turkey, still continuing its work today, is an organization called TÜMATA established in 1976 to investigate and present the origin, development, repertoire and instrumental diversity of Turkish music. During the performing of passive-receptive music therapy tradition developed from Horasan-origin Turkish art music and the 
fullness of Horasan-Anatolian music modes, the patients are in a state of rest sitting or lying in a comfortable position. The goal of this therapeutic modality is to help the patients relax and enhance their self-confidence and thus, alter their emotional state. In this technique performed by TÜMATA today, Horasan-origin Turkish art music and Horasan-Anatolian music modes accompanied by a relaxing rhythm and a soothing water sound are used [14].

In the literature, there has been research conducted with a different patient series, which evaluated the effect of the music therapy on anxiety $[4,13,15-20]$. It is helpful that nurses plan the interventions to reduce the anxiety level of the patients who were to undergo a coronary angiography. Hence, this study was performed to examine the effects of music on anxiety level in the patients undergoing coronary angiograph.

\section{METHODOLOGY}

Sample: The study was conducted experimentally as a pretest/posttest control group design in Istanbul. The total size sample was 200 volunteer patients (control group $\mathrm{n}$ $=100$, study group $\mathrm{n}=100$ ) who were admitted to hospital for a first time coronary angiography, 18 years or older and could read and hear.

Data collection and Instruments: Four tools were used to collect data.

Questionnaire: The questionnaire, which consisted of 15 open-ended and multiple-choice questions, was developed by the researchers according to the literature. It includes socio-demographic features and about music and anxiety questions.

State-Trait Anxiety Inventory: The original scale the "State-Trait Anxiety Inventory" was developed by Spielberger, R.L. Gorsuch and Lushene in 1970. It was adapted for Turkish patients by Öner and Le Compte in 1985 by performing validity and reliability studies [21]. The inventory consists of two separate scales, each of which consisted of the 20 items of the Likert type scale. The state anxiety scale determines how the individual feels at a particular moment and under certain circumstances. The scale is designed in quadruple Likert-type scale varying between "none", "little", "much", and "completely". The trait anxiety scale determines how the individual generally feels, independent of the status and the conditions which surround him/her on a five-point Likert-type scale, ranging between "immediately", "never", "sometimes", "usually", and "almost always". Both scales can be introduced at the same time. In this case, the state anxiety scale was given first, and then the trait anxiety scale. The scales include inverted statements. The scores obtained from both scales range from 20 to 80. High scores indicate elevated anxiety levels and low scores indicate lower anxiety levels. In the present study, the reliability coefficient range was found to be 0.91 for the trait anxiety scale and 0.93 for the state anxiety scale.

CD and CD player: The CD includes an instrumental piece in the "Hüseyni" mode consistent with the definition of "sedative music." The Hüseyni mode, creating a feeling of peace and tranquility, generates self-confidence and a sense of determination because of its hidden pentatonic composition. It is used as music therapy for patients with cardiac, liver and gastric disorders [14]. All music was instrumental without words. In the music piece, with the rhythm and water sound, an improvisation (partition with rhythm) with Ney, Rebab, Çeng, Ud, Dombra and Rübab is performed.

Procedure: The patients were divided randomly into study and control groups. The study group comprised of patients who had an odd protocol number, and the control group had an even number. In the waiting room, 10 minutes before the procedure, the questionnaire with state and trait anxiety scales was given in that order. The control group received standard care; the study group received standard care and music intervention. It was explained to the study group that the music was to be played in the room for the study. For study group, the music began in the operating theatre before the entrance of the patient and continued until the patient left the room. After the procedure, the patients in both groups answered the state anxiety scale questions once again.

Data analysis: Data were analyzed using SPSS (version 11.5 ) by a statistician. Percentages of socio-demographic characteristics were computed. The paired t-test and $t$ test were used for the evaluation. The significance level was $\mathrm{p}<0.05$.

Ethical considerations: Before the study, the approval to conduct the study was obtained from the Ethics Committee of the Hospital. The informed consents of the patients were obtained.

\section{RESULTS}

Demographic characteristics of the patients were shown in Table 1. In the study, the average scores of the trait anxiety and the average scores of the state anxiety scores were evaluated before and during the coronary angiography (Figure 1 and Table 2), and the differences between the average points of the state anxiety scale were obtained before and during the coronary angiography (Table 3). As seen in Table 2, the average scores of the pre-angiography state anxiety of both study groups and control groups were statistically higher than the average scores of the intraoperative state anxiety (study groups: $p=0.000$; control groups: $p=0.000$ ). With regard to the differences between the average scores of state anxiety obtained before and during the coronary angiography (Table 3), the difference between the state anxiety scores 
Table 1. Demographic characteristics of the patients.

\begin{tabular}{|c|c|c|c|c|c|c|c|}
\hline \multicolumn{2}{|c|}{ Characteristics } & \multicolumn{2}{|c|}{$\begin{array}{l}\text { Control Group } \\
\quad(n=100)\end{array}$} & \multicolumn{2}{|c|}{$\begin{array}{l}\text { Study Group } \\
\quad(\mathbf{n}=\mathbf{1 0 0})\end{array}$} & \multicolumn{2}{|c|}{$\begin{array}{c}\text { Total } \\
(\mathbf{N}=\mathbf{2 0 0})\end{array}$} \\
\hline & & n & $\%$ & $\mathbf{n}$ & $\%$ & $\mathbf{n}$ & $\%$ \\
\hline \multirow{2}{*}{ Gender } & Female & 31 & 31 & 29 & 29 & 60 & 30 \\
\hline & Male & 69 & 69 & 71 & 71 & 140 & 70 \\
\hline \multirow{3}{*}{ Age } & $18-45$ & 18 & 18 & 26 & 26 & 44 & 22 \\
\hline & $46-65$ & 61 & 61 & 52 & 52 & 113 & 56.5 \\
\hline & 66 and up & 21 & 21 & 22 & 22 & 43 & 21.5 \\
\hline \multirow{2}{*}{ Educational Status } & Elementary & 65 & 65 & 47 & 47 & 112 & 56 \\
\hline & Lise (After Elementery) & 35 & 35 & 53 & 53 & 88 & 44 \\
\hline \multirow{3}{*}{ Marital Status } & Married & 91 & 91 & 99 & 99 & 190 & 95 \\
\hline & Single & 4 & 4 & 1 & 1 & 5 & 2.5 \\
\hline & Widow & 5 & 5 & 0 & 0 & 5 & 2.5 \\
\hline \multirow{3}{*}{ Working Status } & Working & 43 & 43 & 26 & 26 & 69 & 34.5 \\
\hline & Retired & 41 & 41 & 61 & 61 & 102 & 51 \\
\hline & Not Working & 16 & 16 & 13 & 13 & 29 & 14.5 \\
\hline \multirow{2}{*}{ Previous Hospital Experience } & Yes & 25 & 25 & 25 & 25 & 50 & 25 \\
\hline & No & 75 & 75 & 75 & 75 & 150 & 75 \\
\hline
\end{tabular}

Table 2. State anxiety scores obtained before and during coronary angiography.

\begin{tabular}{ccc}
\hline \multirow{2}{*}{ State Anxiety Scores } & Control Group $(\mathrm{n}=100)$ & Study Group $(\mathrm{n}=100)$ \\
\cline { 2 - 3 } & Mean \pm S.D & Mean \pm S.D \\
\hline Before The Coronary Angiography & $37.61 \pm 1.43$ & $35.11 \pm 1.28$ \\
During The Coronary Angiography & $35.60 \pm 1.42$ & $31.07 \pm 0.98$ \\
$\mathrm{t}$ and $\mathrm{p}$ & $\mathrm{t}=201 ; \mathrm{p}=0.000$ & $\mathrm{t}=35.28 ; \mathrm{p}=0.000$ \\
\hline
\end{tabular}

The paired t-test.

Table 3. The differences between average scores of state anxiety before and during the coronary angiography.

\begin{tabular}{|c|c|c|c|}
\hline \multirow{3}{*}{$\begin{array}{c}\text { The Differences of Average } \\
\text { Scores }\end{array}$} & Control Group $(n=100)$ & Study Group $(\mathrm{n}=100)$ & \\
\hline & Mean \pm S.D & Mean \pm S.D & \\
\hline & $2.01 \pm 0.10$ & $4.04 \pm 1.15$ & $\mathrm{t}=17.66 ; \mathrm{p}=0.000$ \\
\hline
\end{tabular}

t test.

obtained before and during the coronary angiography in the study group (Mean $=4.04$; S.D. $=1.15$ ) were found to be significantly higher than the difference between the average scores of the control group (Mean $=2.01$; S.D. $=$ $0.10)(\mathrm{t}=17.66 ; \mathrm{p}=0.000)$.

\section{DISCUSSION}

In this study on investigating the effects of music on the level of anxiety, the average trait anxiety scores of the patients were found to be similar (Figure 1). This indicates that the patients forming the study and control groups were equal in terms of trait anxiety and thus, reflects the homogeneity of the groups in terms of anxiety.

In both groups, the average state anxiety scores obtained before the coronary angiography were signifycantly higher than those obtained during the intervention $(\mathrm{p}<0.01)$ (Table 2). Any situation that is unknown and experienced for the first time creates anxiety for any 


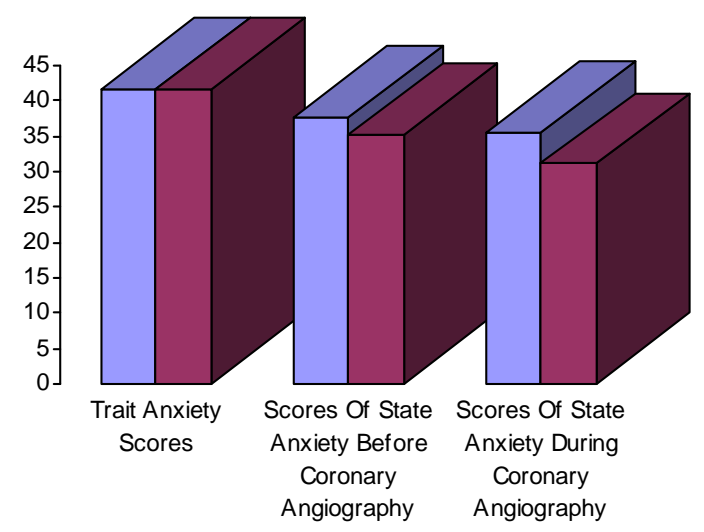

Figure 1. State-trait anxiety scores of the groups.

given person. Being ill, hospitalized, or being exposed to medical intervention for the purpose of diagnosis or treatment in itself generates stress and may cause anger, fear, rage, anxiety and worry [22]. All patients in our study group experienced a sense of worry because an angiography was to be performed on them for the first time which they had never experienced before. During the procedure, that feeling of worry is reduced. Our findings confirm the conclusions of other reports; Baram (1992) conducted a study to evaluate the anxieties of patients undergoing a coronary angiography [23]. In Baram's study (1992), the researcher found the average scores of pre-operative state anxiety $(40.85 \pm 11.95)$ to be lower than the average scores of post-operative state anxiety $(28.67 \pm 9.58)$.

Music therapy allows the individual to become more comfortable, relaxed and be removed from the ambience [10]. The music therapy in the Hüseyni mode, as used in our study, in particular, generates a sense of peace and calm, reducing the level of anxiety by relieving worry and stress [23]. A significant decrease during the coronary angiography anxiety level was observed in both the study and control groups. However, the decrease was significantly more in the patients from the study group when compared with the control group (Table 3). Our result demonstrates that listening to music has a positive impact on intraoperative anxiety levels and that music therapy is efficacious in relieving the anxiety of the individuals.

Varol \& Özbayır (2000) in a study investigating the impact of sedative music on patients' anxiety level in the preoperative period, found the preoperative anxiety score of surgical patients forming the study group to be $37.7 \pm$ 8.9 and the postoperative average score to be $30.45 \pm 6.8$; the author showed that the difference was significant. The authors denoted that the patients participating in the study perceived the music therapy as very relaxing and thus, relieved the stress of the patients [13].

In an experimental study with 60 patients undergoing chemotherapy to ascertain the effect of music therapy on anxiety level, Yıldırım \& Gürkan (2007) found that music has a meaningful relationship with respect to anxiety states of the sample group ( $p>0.05)$, and had no such relationship with the side effects of chemotherapy ( $\mathrm{p}<$ 0.001 ) [24]. The investigation showed that, the clinical use of music as an alternative therapy has positive results in the reduction of anxiety in patients. In our literature, there are also similar results [6].

In an experimental study conducted by Moradipanah et al. (2009) to investigate the effects of the music on anxiety, stress and depression levels, the researchers showed that the music listened to reduced the anxiety, stress and depression levels despite the patients being aware of the fact they were undergoing the invasive procedure of an angiography; the patients were also calmer [25]. Nillson (2009) investigated the effects of listening to music on anxiety levels of patients who had undergone coronary by-pass surgery during bed rest and argued that sedative music was an efficacious alternative treatment method to alleviate anxiety during the postoperative period [19].

\section{CONCLUSION}

As a result of the study, among the patients undergone coronary angiography, it was observed that there was a significant decrease in the average scores of the state anxiety scores in the patients who were played music to. Music therapy affected the intraoperative anxiety level of the patients who had undergone a coronary angiography. Considering that it is a simple, inexpensive and efficacious method, the use of music therapy can be recommended as an appropriate approach for patients who are to have a coronary angiography.

\section{ACKNOWLEDGEMENTS}

The study was conducted for postgraduate thesis for a post graduate program in the Nursing Department at the Halic University Health 
Sciences Institute. It was presented as a poster at the 14th Nursing Research Conference held on November 9-12, 2010 in Spain.

\section{REFERENCES}

[1] Taylor-Piliae, R.E. and Chair, S.-Y. (2002) The effect of nursing interventions utilizing music therapy or sensory information on Chinese patients' anxiety prior to cardiac catheterization: A pilot study. European Journal of Cardiovascular Nursing, 1, 203-211.

[2] Cimilli, C. (2001) Cerrahide anksiyete. Klinik Psikiyatri Dergisi, 4, 182-186.

[3] Arslan, S., Özer, N. and Özyurt, F. (2008) Effect of music on preoperative anxiety in men undergoing urogenital surgery. Australian Journal of Advanced Nursing, 26, 4654.

[4] Hamel, W.J. (2001) The effect of music intervention on anxiety in the patients waiting for cardiac catheterisation. Intensive and Critical Care Nursing, 17, 279-285. doi:10.1054/iccn.2001.1594

[5] Yildirim, N. (2009) Sağlık bakım profesyonelleri ile hasta iletişimi. İn: Sabuncu, N. and Akça Ay, F., Eds., Klinik Beceriler, Să̆lı̆̆ın Değerlendirilmesi Hasta Bakımı ve Takibi, Nobel Matbaacılık, İstanbul, 161-195.

[6] Koç, H., Erk, G., Apaydın, Y., Horasanlı, E., Yiğitbaşı, B. and Dikmen, B. (2009) Epidural anestezi ile herni operasyonu uygulanan hastalarda klasik Türk müziğinin intraoperatif sedasyon üzerine etkileri. Journal of Turkey Anaesthesia and Intensive Care, 37, 366-373.

[7] Lippi, D., Roberti, di Sarsina, P.R. and D'Elios, J.P. (2010) Music and medicine. Journal of Multidisciplinary Healthcare, 3, 137-141doi:10.2147/JMDH.S11378

[8] Kang, J.-G., Lee, J.-J., Kim, D.-M., Kim, J.-A., Kim, C.-S., Hahm, T.-S. and Lee, B.-D. (2008) Blocking noise but not music lowers bispectral index scores during sedation in noisy operating rooms. Journal of Clinical Anesthesia, 20, 12-16. doi:10.1016/i.jclinane.2007.06.005

[9] Gfeller, K. (2003) Therapeutic power of music. Currents, 4:3.

[10] Çoban, A. (2005) Müzik Terapi, Timaş Publishers, İstanbul.

[11] Lee, D., Henderson, A. and Shum, D. (2004) The effect of music on preprocedure anxiety in Hong Kong Chinese day patients. Journal of Clinical Nursing, 13, 297-303. doi:10.1046/j.1365-2702.2003.00888.x

[12] Hayes, A., Buffum, M., Lanier, E., Rodahl, E. and Sasso, C. (2003) A music intervention to reduce anxiety prior to gastrointestinal procedures. Gastroenterology Nursing, 26, 145-149. doi:10.1097/00001610-200307000-00002
[13] Varol, Ş. and Özbayır, T. (2000) Sedatif müziğin preoperatif kayg1 düzeyine, intraoperatif kan basınc1 ve nabız parametrelerine etkisi. Hemşirelik Forumu Dergisi, Ameliyathane Özel Sayısı, 3, 15-18

[14] Güvenç, O. (2005) Gül ve bülbül. Tümata Derneği Yayınlarl, April: 4-6.

[15] Stuckey, H. and Nobel, J. (2010) The connection between art, healing, and public health: A review of current literature. American Journal of Public Health, 100, 245263. doi:10.2105/AJPH.2008.156497

[16] Bolwerk, C. (1990) Effects of relaxing music on state anxiety in myocardial infarction patients. Critical Care Nursing Quarterly, 13, 63-72.

[17] Bally, K., Campbell, D., Chesnick, K. and Tranmer, J. (2003) Effects of patient-controlled music therapy during coronary angiography on procedural pain and anxiety distress syndrome. Critical Care Nurses, 23, 50-57.

[18] Bradt, J. and Dileo, C. (2009) Music for stres and anxiety reduction in coronary heart disease patients. The Cochrane Library, 2, 1-79.

[19] Nilsson, U. (2009) The effect of music intervention in stres response to cardiac surgery in a randomized clinical trial. Heart \& Lung: The Journal of Acute and Critical Care, 38, 201-207. doi:10.1016/j.hrtlng.2008.07.008

[20] Chan, Y.M., Lee, P.W.H., Ng,T.Y., Ngan, H.Y.S. and Wong, L.C. (2003) The use of music to reduce anxiety for patiens undergoing colposcopy: A randomized trial. Gynecologic Oncology, 91, 213-217. doi:10.1016/S0090-8258(03)00412-8

[21] Öner, N. and LeCompte, A. (1985) Durumluluk-Sürekli Kaygı Envanteri El Kitabı. Boğaziçi Üniversitesi Basımevi, İstanbul.

[22] Nilsson, U., Lindell, L., Eriksson, A. and Kellerth, T. (2009) The effetct of music intervention in relation to gender during coronary angiographic procedures: A randomized clinical trial. European Journal of Cardiovascular Nursing, 8, 200-206.

[23] Baram, Z. (1992) Koroner anjiyografi olacak hastlarının anksiyetelerinin giderilmesi. Master's Thesis, İstanbul University Institue of Medical Sciences, İstanbul (unpublished).

[24] Yildırım, S. and Gürkan, A. (2007) The influence of music on anxiety and the side effects of chemotherapy. Anadolu Psikiyatri Dergisi (Anatolian Journal of Psychiatry), 8, 37-45.

[25] Moradipanah, F., Mohammadi, E. and Mohammadil, A.Z. (2009) Effect of music on anxiety, stress and depression levels in patients undergoing coronary angioraphy. Eastern Mediterranean Health Journal, 15, 639-647. 